\title{
The Obstacles of Geographical Information System (GIS) Development: A Study of Teachers' Distribution in Sukabumi, Indonesia
}

\author{
Dr. Ahmad Yani, M.Si. \\ Departemen Pendidikan Geografi \\ Universitas Pendidikan Indonesia \\ Bandung, Indonesia \\ ahmadyani@upi.edu
}

\begin{abstract}
Geographical Information System (GIS) is an application used to process data in form of thematic maps, which is arranged overlapping to produce informations needed by the user. Employing descriptive method, this study indicated that basically the GIS development was relatively easy, but its sustainability was considered to be difficult. The Education Office of Sukabumi district have built the GIS since 2017, but the absence of GIS manager and operator made it not optimally utilized. To develop sustainable GIS, it is considered to go on these three steps, (1) Increasing the commitment of the leaders of Education Office to optimally utilize GIS in every policy making, (2) Increasing the quality of GIS management to help the process of every policy making, (3) Providing GIS manager and operator bound in official duty in the office.
\end{abstract}

Keywords-Distribution; Education; GIS; Sukabumi; Teacher

\section{INTRODUCTION}

Currently, GIS have already been utilized in education management. Mulaku \& Nyadimo (2011) called it Educational Management Information System (EMIS) which contain information about location of the schools; the total number of existing schools at primary, secondary and tertiary levels in the public and private sectors; their capacities, physical condition and facilities, the number of students of each sex attending each school, plus the number of teachers at each school and their qualifications ${ }^{1}$.

During 2007-2009 the Education Office of Sukabumi District received fund from Better Employment and Redeployment Management Universal Teacher Upgrading (BERMUTU) for implementing a piloting program of GIS for teachers' distribution and deployment. The program has generated data base in map form displays administrative boundaries of each sub-district, location of schools in every sub-district, total number of teacher in each school, studentteacher ratio in each school, teacher employment status, and mismatch identification of teacher qualification with his or her duty of teaching in each level of education.

\author{
Rosita, S.S., M.A \\ Manajemen Resort and Leisure \\ Universitas Pendidikan Indonesia \\ Bandung, Indonesia \\ rosita@upi.edu
}

GIS development stage in Sukabumi district has already pass through a number of standard processes such as storing, retrieving, manipulating, analyzing, and displaying geographical data information ${ }^{2}$. This study is considered necessary since GIS has not yet been optimally utilized in Indonesia, especially for education planning. While in developed countries, GIS has been applied in many areas for its advantages to analyze, understand, and manage the earth in nearly every sector of society, including education ${ }^{3}$. In Indonesia there are still obstacles in almost every step of GIS development especially in place of study.

This study tried to reveal obstacles in GIS development in relation with decision-making process in education management especially teachers' distribution. Benefits of this study are (1) able to describe the process of GIS development in education, (2) able to describe obstacles faced by GIS developer especially in place of the study, (3) able to give insight to education offices in Indonesia in finding solutions for GIS development problems.

\section{METHODS}

This study employed descriptive method to describe GIS development process for teachers' distribution in Sukabumi district from 2007 to 2009, obstacles and failure in developing GIS technically and its policies. Data were collected from interview with informants from Education Office of Sukabumi district, and documentation study. Data were analyzed by qualitative approach and withdrawal conclusions were transferable.

\section{RESUlT AND Discussion}

Results of this study will be explained in three parts, GIS development for teachers' distribution, GIS data analysis for teachers' distribution planning, and obstacles of GIS development in place of study.

\section{A. GIS development for teachers' distribution}

Developing GIS for teachers' distribution as explained above should go through several stages such as, storing, retrieving, manipulating, analyzing, and displaying geographical data information ${ }^{2}$. Data storing were done gradually, started from provision of analogous earth map 


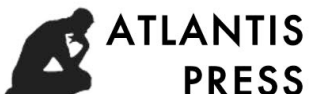 PRESS}

which is converted to vector data ${ }^{5}$ through digitizing process. The earth map was obtained from Survey and National Mapping Coordination Board or now called Geospatial Information Board. Another source of data was analogous map of schools' location obtained from The Ministry of National Education's GIS management team in 2007. Prior to digitizing, the schools' location was plotted through verification by the head of technical unit of Sukabumi District Education Office.

Data retrieving is a process of adjusting available data at Sukabumi District Education Office with formatting table requested by GIS program (Arc View). At this stage two problems were identified, first was at the plotting stage where there were many locations of the schools were not known on the map. Second was the number and variety of columns on the database. To handle those problems several meetings were held gradually inviting head masters of several schools and the head of technical unit of Sukabumi district Education Office

The next step was data manipulating including converting the analogous map coordinates into global positioning system (GPS) coordinates. Difficulty was found during this manipulating process because several maps of sub-district offices were not in the same scale. Then annotation of the map was done and it was technically going smooth without any problem since it was only complimentary. However, the problem appeared when the process came into naming the new sub-district since there were only 45 sub-districts in the analogous map, but it increased to 47 sub-districts when the GIS was trying to be developed. The consequences of above problems were difficulties to establish the sub-district boundary lines and tracking names of the schools that their addressed have not been changed yet.

The next step was displaying geographical data information within map in overlaying model. The result was not entirely perfect. Many data were still need to be interpreted to be able to understand by the user. As an example, teachers' distribution map cannot be seen in subdistrict map, but it can be seen only in the symbol of schools' location with certain color. The color of the symbols were based on the ratio data between the number of teachers and students. After the ratio is known, then the color will show which sub-districts are having more teachers and which ones are not. So it can be decided that sub-district with more teachers cannot take transferred teachers from other subdistricts.

The teachers' data based on their academic qualification, which one have already had their bachelor degree and which one have not, was trying to be displayed but indirectly since GIS application is only able to display location of the schools with color based on data of teachers with bachelor degree. To handle above problem the GIS developer decided to set red color to indicate schools with 1-5 teachers without bachelor degree, and blue to indicate schools with 6-10 teachers without bachelor degree. To show fully profile of a school with its real number of teachers, an identity window or school's profile table were made as shown in figure 1 .
GIS analysis also has not yet able to show sign of teacher mismatch which show the mismatch between field of study a teacher teach with his or her expertise. It is only able to show mismatch of total number of teachers in a school.

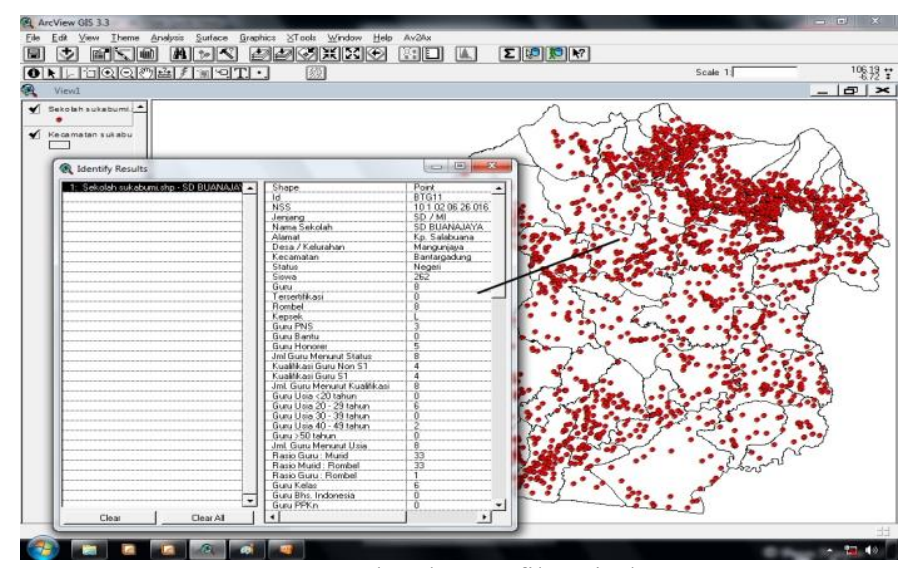

Figure 1: Schools' profile window

Information about activity of replacing retired teachers has also not yet been able to be displayed. The GIS can only show population of the teachers whose ages are more than 50 years old (almost retired age) tied to the location of the school.

\section{B. GIS data analysis for teachers' distribution planning}

Data analysis for teachers' distribution needs at least four steps:

(1) Data analysis for teacher distribution can be based on student-teacher ratio. Basic data needed are the total number of the students and teachers, administration region, and schools' distribution. It will be grouped into three which are 1) school with student ratio under 28 people, 2) school with student ratio 28 people, and 3) school with student ratio above 28 people. The scheme will be as shown in figure 2 below.

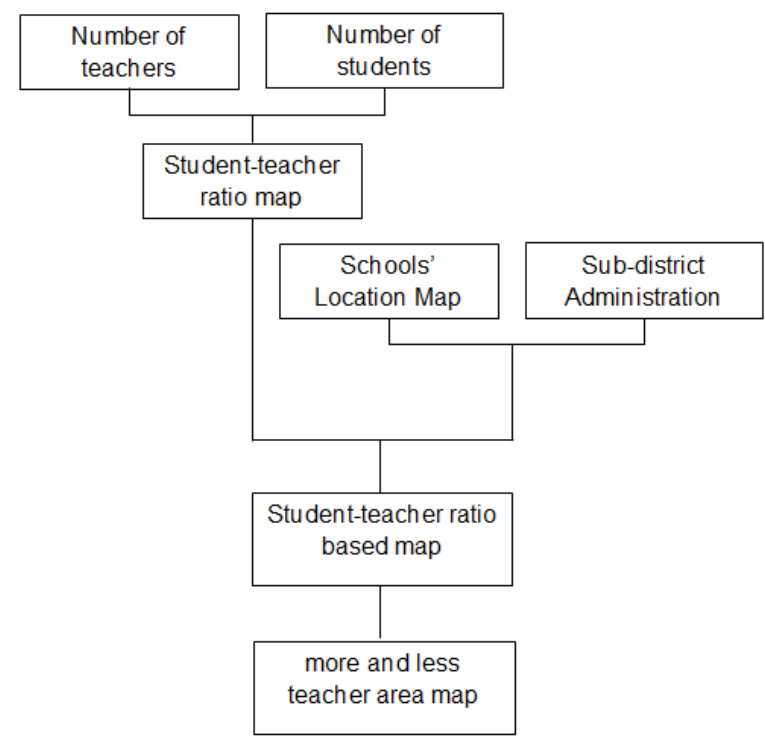

Figure 2: Teachers' distribution mapping scheme 
(2) Data analysis for teacher's qualification. Basic data needed are total number of teachers with bachelor degree and without the degree. To obtain those data below procedure is recommended.

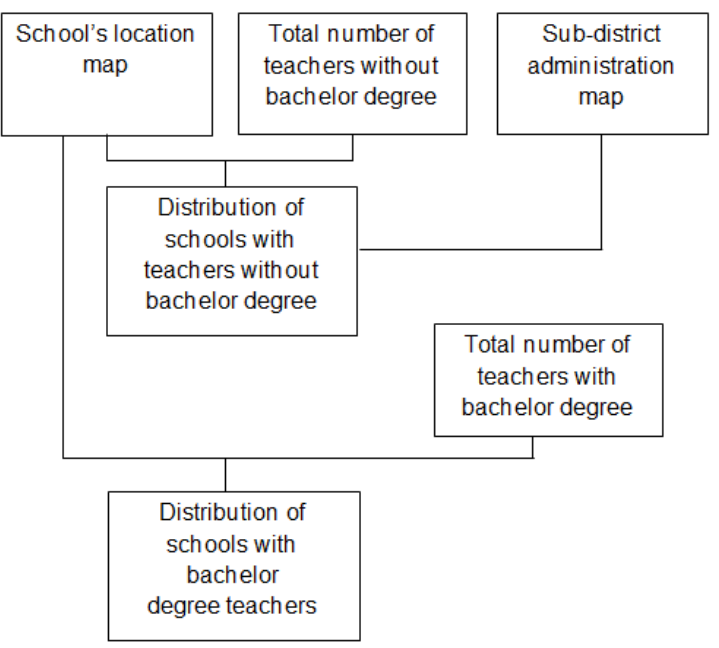

Figure 3: Bachelor degree teachers' distribution scheme

(3) Data analysis for civil and non-civil servant teachers' status. GIS is able to display this information by way of data analysis as follows:

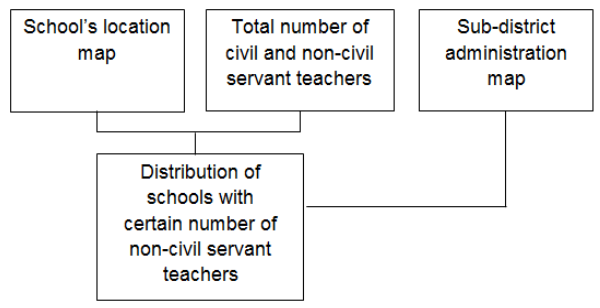

Figure 4: Civil and non-civil servant teachers' distribution scheme

(4) Mismatch analysis. Basic data needed to identify mismatch between field of study a teacher teach with his or her expertise can be analyzed by procedure as follows:

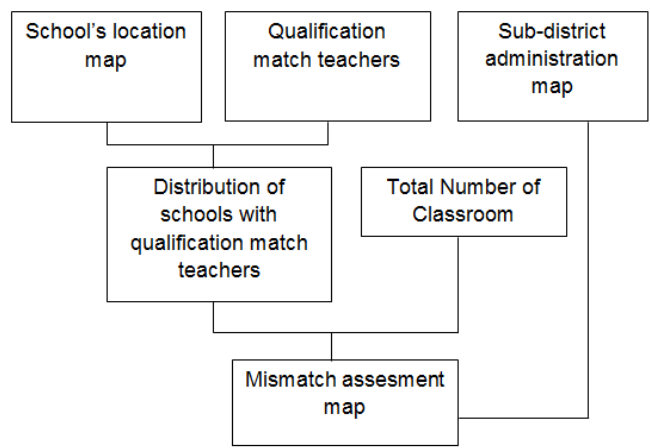

Figure 5 : Mismatch teachers' management efficiency scheme

\section{The obstacles of GIS development in place of study}

Technically, as explained above, GIS development meets obstacles in almost every stage. However, those obstacles have been attempted to overcome. The result is shown from the maps produced by using the GIS.

A significant obstacle, which considered to gives influence to the effectiveness of GIS for teachers' distribution is in the modeling stage. GIS has not yet been very effective in helping the decision making of teachers' distribution because it is not instantly displayed and understood but still need to be interpreted first. As above explanation that GIS can only show the number of studentteacher ratio as the interpretation of teacher's density in a school.

Determination of teachers' distribution based on their academic qualification is still difficult to do since GIS is only able to display the window of schools' profile, but unable yet to display certain color on map which represent teachers' academic qualification. Similar obstacles were also met when the data of civil and non-civil servant teachers tried to be displayed. Mismatch analysis was also unable yet to be implemented perfectly because GIS is only able to display the data on profile window. Hence, it is still needed an indepth study about GIS management and data analysis.

Obstacle was also met in the case of policy. GIS has not yet considered as an important tool to help making decision in teachers' distribution. It because of several factors such as: 1) authority violation in the procedure of transferring teacher from one school to another. In several cases, a teacher was being approved to be transferred by the head of technical unit, while the procedure said it was the head of Education Office has the right to approve it. If this kind of violation continues then GIS is no longer needed in decision making; 2) The Education Office has limited funds while applying, maintaining, and updating data are very expensive; 3) GIS management need professional operators. However, those positions seem less attractive and it is rare to find education staff who is willing to have the position, and 4) GIS management often count on a person as an operator, so that when the person resign and no other person able to operate the system, then all available data is no longer be operated.

\section{CONCLUSION}

Based on the result above, it can be concluded that the GIS development for managing education need higher cost, more time, and energy. Besides, it need more patience and whole-hearted in the process of storing, retrieving, manipulating, analyzing, and displaying geographical data information. All the above processes are not easy, especially in the process of analyzing and displaying the information to be understood by the user and the policy maker. Generally, to overcome obstacles met in GIS development these four steps are needed, 1) commitment of the leaders of Education Office to optimally utilize GIS in every decision making, 2) Utilizing the effectiveness of GIS to innovate way in decision making of teachers' distribution, 3) It is necessary to provide GIS manager and operator as permanent staffs in the office. 


\section{ACKNOWLEDGMENT}

We would like to thank you to The Better Employment and Redeployment Management Universal Teacher Upgrading (BERMUTU) Piloting Program that managed by Direktorat Jenderal Peningkatan Mutu Pendidik dan Tenaga Kependidikan, Direktorat Pendidikan dan Pelatihan, Kepala Dinas Pendidikan Kabupaten Sukabumi, and Ketua Dewan Pendidikan Kabupaten Sukabumi.

\section{REFERENCES}

[1] G.C. Mulaku, G.C. and Nyadimo, E. (2011). Gis In Education Planning: The Kenyan School Mapping Project. Survey Review, 43, 323 pp. 567-578 (October 2011). DOI 10.1179/003962611X13117748892155.

[2] Fitzpatrick, C., and D. J. Maguire. 2000. GIS in schools: Infrastructure, methodology and role. In GIS:Asourcebook for Schools, ed. D. R. Green, pp. 61-62. New York: Taylor \& Francis.

[3] Joseph J. Kerski , Ali Demirci \& Andrew J. Milson (2013) The Global Landscape of GIS in Secondary Education, Journal of Geography, 112:6, 232-247, DOI: 10.1080/00221341.2013.801506

[4] Shenton, AK. 2004. Strategies for ensuring trustworthiness in qualitative research projects. Education for Information 22 (2004) 63-75 63. IOS Press.

[5] Lwin, KK; Murayama, Y; Mizutani, C. 2012. Quantitative versus Qualitative Geospatial Data in Spatial Modelling and Decision Making. Journal of Geographic Information System, 2012, 4, 237-241 http://dx.doi.org/10.4236/jgis.2012.43028 Published Online June 2012 (http://www.SciRP.org/journal/jgi) 